\title{
ODHALOVÁNÍ, HARMONIZACE A RYTMUS BEZPROSTŘEDNOSTI VE WHITEHEADOVÝCH A BERGSONOVÝCH ÚVAHÁCH O ROLI UMĚLECKÉHO DÍLA A POVAZE ESTETICKÉ ZKUŠENOSTI
}

\author{
MILOŠ ŠEVČíK \\ Katedra estetiky, Filozofická fakulta, Univerzita Karlova \\ Katedra filozofie, Fakulta filozofická, Západočeská univerzita v Plzni \\ E-mail: milossevcik@yahoo.com
}

\begin{abstract}
The Revealing, Harmonization, and Rhythm of Immediacy in Whitehead's and Bergson's Writings about the Role of the Work of Art and about the Nature of Aesthetic Experience
\end{abstract}

In this essay, the author seeks to demonstrate the remarkable resemblance between the ideas of Alfred North Whitehead and those of Henri Bergson concerning the role of art and aesthetic experience generally in revealing the appearance of immediate experience. The two philosophers agree that this reality is usually concealed from human considerations about practical possibilities of using reality, including considerations about the communicability of the nature of reality. Both men also agree that this revealing has the form of the harmonization of the usual unfocused experience of things and feelings. Nevertheless, in this article the author seeks to demonstrate that harmonization assumes the form of rhythmic arrangement, and art and aesthetic experience therefore generally show immediate reality as rhythm. The fact that immediate experience is rhythm appears, when seen from the standpoint of the conception of Whitehead and Bergson, to be natural, because all reality has the nature of a spectrum of rhythmic movements. By comparing the ideas of the two philosophers, the author aims not only to provide a more precise outline of their thinking on this subject, but also to point out that the similarities of their views enable us to explain them, make them more precise, and to develop them.

Keywords: H. Bergson; A. N. Whitehead; immediacy; harmonization; rhythm

\section{I. Úvod}

V následující studii chceme poukázat na pozoruhodnou př́buznost názorů Alfreda Northe Whiteheada a Henriho Bergsona na roli umění a estetické zkušenosti obecně v odhalování podoby bezprostřední zkušenosti. Oba autoři se shodují v tom, že tato skutečnost je obvykle zakryta lidskými ohledy na praktické možnosti využití skutečnosti, a to včetně ohledů na sdělitelnost povahy skutečnosti. Oba autoři jsou také shodně přesvědčeni, že toto odhalování má podobu harmonizace obvyklé nesoustředěné zkušenosti věcí a pocitů. Pokusíme se však zejména ukázat, že sama harmonizace na sebe bere podobu rytmického uspořádání, a že tedy umění a estetická zkušenost obecně ukazuje bezprostř̌ední skutečnost jako rytmus. To, že je bezprostřední zkušenost rytmem, se z hlediska koncepcí obou sledovaných autorů jeví jako přirozené, protože celá skutečnost má charakter spektra rytmických pohybů. Následující studie chce přesněji vymezit obrysy názorů obou autorů na tato témata za pomoci jejich vzájemné komparace, ale i poukázat na 
to, že blízkost názorů Whiteheada a Bergsona umožňuje tyto názory na základě vzájemné komparace vykládat, upřesňovat a doplňovat. ${ }^{1}$

\section{Umělecké odhalování bezprostřednosti}

V pojednání Symbolismus, jeho význam a účin (1927) hovoří Whitehead o „fundamentálním symbolismu“, s nímž se v životě velmi často setkáváme. ${ }^{2}$ Zmíněný symbolismus spočívá např́iklad v převedení barvy a tvaru na předmět. Ve skutečnosti vidíme „zbarvený tvar“, ovšem řekneme, že je to třeba židle. Proti tomuto obvyklému postupu fundamentálního symbolismu staví Whitehead schopnost umělce. Umělec „nemusí " přeskočit k tomuto dojmu židle, a je schopen se zastavit u „čiré kontemplace barvy a tvaru“ 3 My ostatní naopak, $v$ rámci naší běžné každodenní zkušenosti, přecházíme př́mo od percepce barvy a tvaru k prožitku židle, ke kterému přistupujeme z hlediska určitého „použití, citu nebo myšlení. K takovému přechodu není zapotřebí žádného zvláštního výcviku, naopak je velice snadný, lidé i zvířata jsou k němu velmi náchylní. Tento přechod je "přirozený“, podstupují ho lidé i štěňata, lidé i štěňata jednají ve zmíněné situaci na základě hypotézy židle, na kterou se dá posadit nebo vyskočit. K získání percepce barvy a tvaru je naopak - a to i v prrípadě umělce - zapotřebí „složitého výcviku“, $\mathrm{k}$ „čiré kontemplaci barvy a tvaru“ dokážeme přistoupit, jen když vyvineme značné „úsilí“.

Toto vnímání barvy a tvaru bez symbolického přechodu k předmětu kvalifikuje Whitehead jako „prezentující bezprostřednost“. 4 V prezentující bezprostřednosti nejsou k dispozici „abstraktni““ či „univerzálni““ rysy. Např́klad v př́ípadě vnímání zdi má prezentující bezprostřednost charakter skutečnosti, kterou je „,barva této zdi pro nás“, nikoli abstraktně určené barvy nebo rozlohy, nebo dokonce typu předmětu. Tato abstraktně určená barva nebo rozloha či výslovné určení typu předmětu je „rouškou“ položenou na fakt, kterým je „,barva této zdi pro nás“ v prezentující bezprostřednosti. Tato abstrakce zdi je odvozena $\mathrm{z}$ jiného typu zkušenosti, a to z konceptuální analýzy kauzality věcí, tedy z konceptuálního uchopení jejich povahy a funkční návaznosti, kterou dokážeme vyjádřit pomocí slov.

V Bergsonových úvahách se setkáváme s velice podobným motivem. Bergson opakovaně poukazuje na to, že obvykle nejsme schopni vnímat individualitu věcí a vlastních

1 Domníváme se, že Keith Robinson oprávněně konstatuje, že to, co spojuje Bergsona s Whiteheadem a také s Deleuzem - je to, že tito autoři zdůrazňují „implicitní estetickou genezi, uspořádání a tvořivé uspořádání zkušenosti“, a to ve „zkušenosti rozšírené, nikoli jednoduše rovnající se zkušenosti lidské“. Zde a dále srov. K. Robinson, Introduction: Deleuze, Whitehead, Bergson - Rhizomatic Connections, in: K. Robinson (ed.), Deleuze, Whitehead, Bergson. Rhizomatic Connections, Palgrave Macmillan, Houndmills, 2009, s. 22. Konkrétnější pohled na takovýto rozvoj „metafyziky ve vztahu k estetice“ u zmíněných myslitelů však už Robinson nenabízí. Doufáme, že přeložená studie je schopna poskytnout relativně plastický pohled na spojitost mezi Bergsonem a Whiteheadem v pojetí rytmického charakteru estetické zkušenosti, ale i rytmického uspořádání skutečnosti jako takové. Na možnosti pojetí vztahu mezi Bergsonem a Whiteheadem na obecnější úrovni jejich myšlení jsme upozornili v předcházející studii. Srov. M. Ševčík, Umělecká tvořivost v úvahách A. N. Whiteheada a H. Bergsona. Acta Universitatis Carolinae. Philosophica et Historica. Studia Aesthetica, č. 1, 2017, s. 51-52.

Zde a dále srov. A. N. White srov. tamtéž, s. 3 .

4 Zde a dále srov. tamtéž, s. 16-18. 
pocitů. Z toho důvodu existuje umění: umění zprostředkuje, či přesněji řečeno sugeruje tuto individualitu, tedy to, co jsme pravděpodobně zahlédli, čeho jsme si však ve vlastním smyslu nepovšimli. ${ }^{5}$ Ve Smíchu Bergson důrazně upozorňuje na to, že obvykle se pohybuje v oblasti „obecnosti a symbolư", 6 kterými jsou ve vnímání i pocitování nahrazeny individuální charakteristiky. A to z toho důvodu, že obecnost je to, co postačuje k praktické činnosti. K činnosti za účelem našeho prospěchu plně dostačuje rozeznat druh věci, soustředění se na zvláštní či individuální rysy je nadbytečné. Tuto tendenci dále posiluje používání slov. Ve slovech je vždy zaznamenáno to obecné z věcí a citů, to, co může být sdíleno, to, co může být kýmkoli sdělováno. Takovýto prakticky motivovaný přístup ke skutečnosti je naprosto obvyklý. Jedině umělci jsou v některém směru, v některém smyslu od této převahy hlediska praktického prospěchu osvobozeni. ${ }^{7}$ Umělci jsou schopni vidět, slyšet a cítit skutečnost a tuto individuální skutečnost sdělují, či lépe řečeno vnucují ostatním. ${ }^{8}$ Inspirováni umělci mohou pak i ostatní lidé přistoupit k odhalení „závoje“, kterým je pro ně realita překryta. I ostatní lidé pak mohou nahlédnout individualitu věcí i vlastního života. Také oni tedy mohou přistoupit k bezprostřednosti sebe sama a věcí, mohou ke skutečnosti přistoupit - můžeme doplnit Bergsona - v estetické zkušenosti. Nakaženi příkladem umělce dokážou také ostatní lidé alespoň poodhrnout část závoje a v některém směru se zachvět „V souladu s přírodou“, „vymezit v prostoru a upevnit v čase nenapodobitelné obrazy“. 9 Je to „příroda“ v nenapodobitelných a neopakovatelných „barvách a tvarech“, je to skutečnost citu, „prostý stav duše jedince“, a nakonec je to skutečnost individuálního „zákona“ proměnlivosti citů, jejich souladů a kontrastů. ${ }^{10}$

V Symbolismu uvažuje Whitehead o dvojím symbolickém vztahu mezi jazykem a bezprostředním působením věcí. Básník vychází od působení věcí, například lesa, a vzhledem k tomuto působení, k tomuto zanícení, vyhledává ve „vytržení, či dokonce tvưrčích „mukách“ vhodná slova. ${ }^{11}$ Vyhledává tedy vhodná slova, kterým by toto zanícení odpovídalo, či by se snad dalo říci, že si je působením věcí nechá „vnuknout“. Je tedy zřejmé, že básník vyhledává prostředky ke sdělování působení věcí, ke sdělování emocí vyvolávaných v interakci věcí a jeho těla. Čtenář básně naopak postupuje od slov nalezených básníkem $\mathrm{k}$ působení věcí, $\mathrm{k}$ „vizuálním obrazům, zvukům a emocím“. Toto působení věcí, zanícení básníka v lese, je symbolizováno básní. V Symbolismu se však také setkáváme s popisem možností specifického používání slov básníkem či obecně literátem, kterými je čtenáři předkládána bezprostřednost. Na jedné straně je pravda, že slova nedokážou zaznamenat bezprostřední působení věcí, že jsou vždy poznamenána směřováním k abstraktnosti či univerzálnosti. Na straně druhé však také platí, že bezprostřednost působení předávaná pomocí slov se může odvozovat i ze slov samotných. Whitehead v této souvislosti poukazuje na to, že umělecká literatura je obecně založena na souběžnosti dvojího působení slov, na symbolizaci jejich základního významu - významu v podstatě univerzálního či abstraktního - a na symbolickém asociativním spojení těchto slov s je-

\footnotetext{
H. Bergson, Vnímání změny, in: H. Bergson, Myšlení a pohyb, Mladá fronta, Praha 2003, s. 146.

6 Zde a dále srov. H. Bergson, Le rire, essai sur la signification du comique, PUF, Paris 1999, s. 116-118.

7 Zde a dále srov. tamtéž, s. 119.

8 Zde a dále srov. tamtéž, s. 124.

9 Tamtéž, s. 115.

10 Srov. tamtéž, s. 120.

11 Zde a dále srov. A. N. Whitehead, Symbolismus, jeho význam a účin, viz výše, s. 15-16.
} 
jich historií, s jejich př́ípadnými dalšími významy nebo s jejich postavením v soudobé literatuře. ${ }^{12}$ Toto podvojné působení slov je v jazyce obvyklé. To je obecná „estetická“ vlastnost jazyka. Nicméně umělecká literatura je na takové asociaci či vágnosti symbolismu založena, cíleně ji využívá. Whitehead upozorňuje na to, že v literatuře symboly „nabírají a shromažduji“ emocionální významnost z vlastní „emocionální historie“.

I k této Whiteheadově úvaze nacházíme u Bergsona paralelní myšlenky. Také Bergson opakovaně uvažuje o vyjádření individuálního pomocí slov, tedy pomocí toho, co individuální principiálně není. Už v Eseji o bezprostředních datech vědomí se Bergson k tomu problému opakovaně obrací. Hovoří tu o „odvážném romanopisci“, který za pomoci slov naznačuje to, co má „neobyčejnou a ilogickou“ povahu. ${ }^{13}$ Ve skutečnosti znamená slovní vyjádření jen „stín“ individuálního citu, který chce romanopisec popsat. Přesto však takový stín umožňuje čtenáři „vytušit“ povahu tohoto citu. V řeči city a myšlenky sestupují do „společenské oblasti“, romanopisec však pomocí „nahromaděni“ popsaných „detailư“ usiluje o návrat „původní a živé individuality“. 14 Obdobně uvažuje Bergson o povaze tvorby literáta ve Dvou zdrojích morálky a náboženství. Hovoří tu konkrétně o dvou možnostech literární tvorby. ${ }^{15} \mathrm{Na}$ jedné straně může literát ve svém díle novými způsoby kombinovat slova, která jako taková jsou už obecně srozumitelná, společensky daná, a vyjadřují tedy obecné skutečnosti. Literát dokonce může slova předem „přizpůsobovat“ jejich využití v nových kombinacích. V takovém případě však zůstává na úrovni rozumové kombinace toho, co je dáno v obecném povědomí jako označení sdílené myšlenky, co má jen povahu vyjádření „společenského výřezu skutečnosti“. Na straně druhé ovšem může postupovat i ambicióznějším způsobem. Může se pokusit o vyjádření něčeho naprosto individuálního, ,jedinečné“ emoce, tedy emoce, se kterou se mohl plně setkat i jen ,jednou v životě“. Tato emoce by se sama vyjevovala ve fragmentech, kterým slova nemohou odpovídat. $\mathrm{V}$ takovém př́padě musí tedy literát přistoupit k tomu, že „znásilní slova a donutí fragmenty“. Jedině za pomocí takových způsobů použití slov, které mají povahu „slovních hříček“, se může pokusit jedinečnou emoci vyjádřit.

Whitehead v Symbolismu dále poukazuje na to, že popsaný vztah mezi věcmi a slovy je jen dokladem obecnější skutečnosti, kterou je vztah mezi „prezentující bezprostředností “ a konceptualizovanou kauzalitou, tedy vztah mezi individuální skutečností věcí a jejich citového působení a zobecnělou či abstrahovanou skutečností, tj. skutečností vyjádřitelnou slovně a př́slušnou k činnosti či jednání. Obecný rozdíl mezi prezentující bezprostředností a kauzální návazností konceptuálně uchopených věcí je odrazovým momentem veškerých umění. Whitehead upozorňuje na to, že všechna umění směřují ke shromaždování emocionální významnosti. Zvlášt patrné je to v hudbě, a to pravděpodobně z toho důvodu, že základní význam je v hudbě velice oslaben. ${ }^{16} \mathrm{~V}$ souvislosti s hudbou Whitehead upozorňuje na to, že hledisko určení kauzální návaznosti věcí, tedy hledisko určení typu či rozložení navzájem spojených věcí, je tu naprosto nepodstatné: například otázka prostorového uspořádání orchestru je v případě poslechu hudební skladby nedůležitá, až zavádějící, na rozdíl od důležitosti prostorového určení ohniska,

12 Zde a dále srov. tamtéž, s. 61 .

13 Zde a dále srov. H. Bergson, Essai sur les donnés immédiates de la conscience, PUF, Paris 1998, s. 99.

14 Zde a dále srov. tamtéž, s. 123.

15 Zde a dále srov. H. Bergson, Dva zdroje morálky a náboženství, Vyšehrad, Praha 2007, s. 182-183.

16 Zde a dále srov. A. N. Whitehead, Symbolismus, jeho význam a účin, viz výše, s. 61-62. 
z něhož přichází zvuk klaksonu nedaleko projíždějícího automobilu, jestliže chceme tuto situaci analyzovat či vyjádřit.

Také v této souvislosti můžeme upozornit na směřování Bergsonových úvah, které se Whiteheadovým značně přibližují. Obdobně jako Whitehead klade Bergson důraz na rozdíl mezi „bezprostředni“ skutečností, kterou v hudbě vnímáme, a prostorovými představami, kterými tuto bezprostřední skutečnost neoprávněně nahrazujeme. Bergson na řadě míst Eseje o bezprostředních datech vědomí odkazuje ke skutečnostem či principům spojeným s hudbou, když popisuje zásadně neprostorovou skutečnost reálného času, tedy bezprostř̌ední danost čistého trvání. Trvání se neskládá z navzájem oddělených momentů, časových bodů rozložených v představě jakoby do prostoru. Trvání naopak představuje neustálou „organizaci“ aktuálního momentu s momenty předchozími, je tedy jako „melodie“, kterou vytvářejí tóny „splývajícími dohromady“. ${ }^{17}$ Oproti homogennímu prostředí prostoru, do kterého se elementy rozkládají vedle sebe, představuje trvání vždy individuální „heterogenitu“ a „konfúzní mnohost“. S takovouto mnohostí se pravděpodobně nejsnadněji setkáme v některé melodii, kterou vytvářejí tóny ve „vzájemném pronikání. Takovou podobu má i rozvoj určitého individuálního citu ve vědomí, který je z tohoto důvodu ostatně také nepopsatelný pomocí slov. ${ }^{18}$

Rozporem mezi hudbou a prostorem se Bergson zabývá též ve studii „Vnímání změny“. Upozorňuje tu na to, že vjem melodie je ve skutečnosti vjemem „nedělitelného“ a čistého pohybu. ${ }^{19}$ Zároveň máme tendenci průběh melodie v její nedělitelné kontinuitě rozdělovat a představovat si rozmístění odlišných not „vedle sebe“. Naše vnímání melodie je kontaminováno představou činnosti, kterou bychom museli vynaložit $\mathrm{k}$ tomu, abychom zaslechnutý zvuk reprodukovali, a je kontaminováno také vizuálními obrazy. Představujeme si např́íklad partituru, na kterou pohlíží dirigent, noty zapsané vedle jiných not, hudebníky hrající vedle sebe, klávesnici nebo zvedající se smyčce. Když však od těchto „prostorových obrazů“ odhlédneme, zůstane bezprostřední skutečnost melodie jako pohybu, proměny v její nedělitelnosti. Kontinuita melodie je nepochybně blízká „hučení hlubokého života“, tedy nerozložitelnému trvání našeho vědomí. Bergson výslovně hovoří o „melodii našeho vnitřního života“, o nedělitelné melodii naší osobnosti. Obdobně jako Whitehead v Symbolismu však také Bergson ve „Vnímání změny“ poukazuje na to, že individualita, na kterou se soustředuje umění, se týká vnitřku i vnějšku, je to kontinuita vnímané proměny naší osobnosti i kontinuita proměny ve vnímání věcí. ${ }^{20}$ Toto umělcovo směřování $\mathrm{k}$ individualitě pocitu, myšlenky či věci Bergson tematizuje i v řadě dalších pojednání. Např́klad ve studii „Život a dílo Félixe Ravaissona“ poukazuje Bergson na to, že malíř pomocí záznamu viditelných rysů - tedy rysů rozložených v prostoru, nejprve prostoru modelu a následně prostoru díla - vybraného modelu směřuje $\mathrm{k}$ „virtuálnímu centru“, které je mimo tyto rysy zachycené na plátně, je „za plátnem“. ${ }^{21}$ Za viditelnými liniemi vidí malíŕ neviditelnou nejzákladnější aspiraci zachycované osoby, skutečnost pohybu jejího myšlení, „prostou myšlenku rovnající se nekonečnému bohatství tvarů

\footnotetext{
Zde a dále srov. H. Bergson, Essai sur les donnés immédiates de la conscience, viz výše, s. 78.

8 Zde a dále srov. tamtéž, s. 98-99.

19 Zde a dále srov. H. Bergson, Vnímání změny, in: H. Bergson, Myšlení a pohyb, viz výše, s. 159-160.

20 Srov. tamtéž, s. 162.

${ }^{21}$ Zde a dále srov. H. Bergson, Život a dílo Félixe Ravaissona, in: H. Bergson, Myšlení a pohyb, viz výše, s. 254-255.
} 
a barev“. Malírovo dílo zpodobuje „individualitu modelu“, nabízí toto „tajemstvi“, které ve viditelné fyziologii dané osoby nejsme schopni přestat číst jen „větu po větě“.

Velice podobně jako Whitehead také Bergson zdůrazňuje, že umělecké dílo směřuje $\mathrm{k}$ vyzdvižení individuality. Toto směřování k individualitě vnitřní i vnější se však v umělcově tvorbě děje pomocí prostředků obecného charakteru, to znamená obecně srozumitelných a použitelných. Jedině s takovými prostředky se dá prakticky zacházet, působit jimi na skutečnost, pracovat s nimi. $Z$ tohoto hlediska nemá umělec jinou možnost.

\section{Odhalování bezprostředního jako harmonizace}

Vyjdeme-li z Whiteheadova rozlišení prezentující bezprostřednosti a konceptualizované kauzality, můžeme odkázat k tomu, že umělecká tvorba spočívá ve sdělování, v symbolizaci prezentující bezprostřednosti. Umělecká tvorba by z tohoto hlediska spočívala v odstraňování roušky konceptualizované kauzality. Tato operace je nepochybně náročná i z toho důvodu, že takovéto odstraňování nevyhnutelně zachází s prostředky, které jsou samy součástí zmíněné roušky. Na jedné straně je zapotřebí přesněji popsat, co toto odstranění roušky v umění znamená, na straně druhé je nutné ukázat, co $\mathrm{z}$ odhalovaného předmětu může umění nabídnout. Je také zřejmé, že toto odstranění a nabídnutí bude ve skutečnosti jedinou procedurou.

Zároveň je však zapotřebí zdůraznit, že emocionalita je uměním skutečně zvláštním způsobem shromaždována. Whitehead upozorňuje na to, že se symbolickým přenosem emocionality v umění je spojený například „postup potlačení nepodstatných detailü“22 Je to tedy postup uspořádání, harmonizace, potlačení či eliminace nepodstatného. Díky takové eliminaci toho, co „oslabuje“ působení emocionality v umění, je dosaženo komplexu emocí, které se vzájemně „zesiluji““23 Takový komplex odlišných, i když vzájemně se podporujících emocí v umění popisuje Whitehead jako „harmonickou“ emocionalitu.

Ve studii „Vnímání změny“ Bergson obdobným způsobem hovoří o zdůraznění toho, co jsme pravděpodobně zahlédli, ale nepovšimli jsme si toho. ${ }^{24}$ Umělec zdůrazňuje něco v proudu vzájemně se potlačujících elementů. Malíri ukazují to, co jsme už vnímali, co však jen „zablesklo“ a „okamžitě zmizelo“, co se ztratilo v davu jiných „bleskových a pomíjivých výjevư“. Tyto výjevy se v naší obvyklé zkušenosti „překrývají jako ,dissolving views“ a svou „Vzájemnou interferencí vytvářejí „bezbarvý vzhled“ věcí. Je zřejmé, že umělec musí zamezit tomuto vzájemnému potlačování, že musí překonat oblast vzájemného překrývání a upozornit na skutečnost, kterou se rozhodl zdůraznit. Toto vzájemné potlačování výjevů, s nímž se obvykle v životě setkáváme, je zapříčiněno naší schopností praktického jednání, se kterým je spojen i způsob vnímání věcí. Toto vnímání vede k přehlížení jednotlivostí a zároveň k tomu, že se od jednoho rozpoznání předmětu v jeho obecném charakteru ihned přesouváme $\mathrm{k}$ dalšímu. Umělec ve svém díle naopak individualitu věci „izoluje“ a „zdo̊razňuje“ a takovým způsobem tuto jednotlivost vnucuje divákovu pohledu. Domníváme se, že v takovémto smyslu hovoří Bergson ve Smíchu

\footnotetext{
Srov. A. N. Whitehead, Symbolismus, viz výše, s. 62.

Zde a dále srov. tamtéž.

4 Zde a dále srov. H. Bergson, Vnímání změny, viz výše, s. 146-147.
} 
o zásahu umělce do našeho „dřív nesoustředěného vnímání, do „tisíců rodících se činư“, kterými je „vykreslen vnějšek citu“ ${ }^{25}$

O harmonizaci elementů v uměleckém díle - konkrétně harmonizaci pocitů - hovoří Bergson ve Dvou zdrojích morálky a náboženství. Zpozorňuje tu na to, že „elementární pocity“ jsou blízké počitkům, které v člověku „vyvolávají věci“ a které prríroda vytváří za účelem nasměrování člověka $\mathrm{k}$ jednání odpovídajícímu jeho potřebám. ${ }^{26}$ Tyto prakticky významné pocity či počitky člověka jsou však svým zařazením do uměleckého díla proměněny $\mathrm{v}$ „harmonické tóny“ emocionálního „zabarveni“ vytvořeného umělcem. Původně navzájem oddělené pocity či počitky, tedy prrírodou už „dané noty“, se musí v uměleckém díle shodnout s vyzněním „nového citu“ představujícího „základní notu“ harmonického naladění.

Vzhledem k tomu můžeme konstatovat, že jak ve věci nezbytnosti odstranění rušivých elementů v uměleckém díle, tak ve věci nezbytného sladění elementů v uměleckém díle obsažených existuje mezi názory Bergsona a Whiteheada pozoruhodná příbuznost.

Co však tato harmonizace přesně znamená? Domnívám se, že Whiteheadovo uvažování o harmonizaci emocionality ze Symbolismu můžeme doplnit úvahami z Dobrodružství idejí. Whitehead tu upozorňuje na to, že umění je spojeno s krásou a pravdou. ${ }^{27}$ Dokonalé umění směřuje ke kráse i pravdě. Pravda umění spočívá v osvobození „intenzity citư“, která se původně rodí v okamžicích nutnosti. ${ }^{28}$ Umění se soustředí na tuto intenzitu a nutnost odstraňuje. Umění „odhaluje vnitřní a naprostou Pravdu o Povaze Věcí'“29 Umožňuje projevení „hloubky citu“ za hranicemi „přesnosti vědomí, vystoupení „živé zkušenosti“, s níž se člověk původně setkává uprostř̌ed nutnosti každodenního života. ${ }^{30}$ Nutnost každodenního života díky umění mizí a síla pocitů zůstává. Umění působí na základě přesvědčivosti pravdy, kterou předkládá. Pravda tedy jednoznačně zvyšuje hodnotu jevu, který je předmětem umění, to znamená předmětu, který se zároveň jeví jako krásný.

Přestože je přesvědčení, že jediným či přednostním předmětem umění je krása, povrchní, zůstává krása v umění neopominutelnou, poukazuje Whitehead v Dobrodružství idejí. Domnívá se, že krása se vyskytuje ve dvou „stupních“ či „modech“, přičemž ten druhý zahrnuje ten první. ${ }^{31}$ Prvním stupněm je krása jako potlačení vzájemného oslabování subjektivních prehenzí objektivních obsahů. Tato krása znamená „zamezení vzájemného potlačování intenzity vznikajících pocitů. Druhým stupněm je krása předpokládající toto zamezení, zároveň však i syntézu, ve které spojení různých prehenzí vyvolává nové kontrasty objektivního obsahu s jinými obsahy. Tyto kontrasty přinášejí nové intenzity pocitů a nové intenzity vyplývající z kontrastu posilují intenzity pocitů z prvního stupně krásy. Tyto intenzity nyní představují části celku, který je silně pocítěn v kontrastu, a naopak celek silně pocítěný v kontrastu přispívá k intenzitě pocítění těchto částí. Subjektivní formy prehenze jsou tedy propleteny v „kontrastech tvořících vzorec“. Krása je takovýto „Vzorec“, je to „harmonie“ vytvořená na základě kontrastu. Krása je určena jako Síla, při-

25 H. Bergson, Le rire, viz výše, s. 119.

26 Zde a dále srov. H. Bergson, Dva zdroje morálky a náboženství, viz výše, s. 32-33.

27 Srov. A. N. Whitehead, Adventures of Ideas, The Free Press, New York 1933, s. 267.

28 Zde a dále srov. tamtéž, s. 272

29 Tamtéž.

30 Srov. tamtéž, s. 271.

31 Tamtéž, s. 252-253. 
čemž tato Síla v sobě zahrnuje „Mohutnost“ jako rozmanitost detailů v účinném kontrastu a „Vlastní Intenzitu“ působení. Maximum „intenzity“ působení se však odvozuje od maxima „mohutnosti“. Krásu jevu z hlediska těchto úvah popisuje Whitehead nakonec takovýmto způsobem:

Jev je krásný, když jsou kvalitativní objekty, kterými je tvořen, propleteny v protikladech uspořádaných do vzorce, takže prehenze celku jeho částí vytváří nejúplnější harmonii vzájemné podpory. To znamená, že pokud kvalitativní rysy celku a těchto částí vstupují do subjektivní formy jejich prehenze, celek zdůrazňuje cit pro části a části cit pro celek a pro sebe navzájem. To představuje harmonii pocitu a s harmonií pocitu je jeho objektivní obsah krásný. ${ }^{32}$

\section{Harmonizace jako rytmus}

Dospíváme tedy k náhledu, že krása je harmonií kontrastů, že spočívá v posilování intenzity působení částí prostřednictvím působení celku, v posilování intenzity celku prostřednictvím působení částí a ve vzájemném vyvolávání jednotlivých rysů tohoto vzorce. V této souvislosti můžeme poukázat na Whiteheadovo vymezení povahy estetické zkušenosti, s nímž se setkáváme ve Whiteheadově pojednání Náboženství ve vývoji (Religion in the Making, 1926). Nepochybujeme, že jsou způsobu přiblížení povahy krásy z Dobrodružství idejí velice blízká. Nová estetická zkušenost vzniká v případě, že „tvořivý účel“ je uspořádán specifickým způsobem. ${ }^{33}$ Estetická zkušenost v sobě zahrnuje nový „důsledek“ (consequent), který si však musí ponechat určitou charakteristiku „příčiny“ (ground) a zároveň - tedy když zachovává tuto charakteristiky příčiny - musí představovat určitý „kontrast“ vưči této příčině. Estetická zkušenost vyvstává tudíž v situaci takového uskutečňování, kdy následek souhlasí s příčinou co do „obecného typu“ a zachovává její „určenost“, a kdy s ní zároveň „kontrastuje“. Ve vztahu takovýchto „protikladných instancí“ je získána „živost a kvalita“ zkušenosti, kterou z toho důvodu můžeme nazývat estetickou. Domníváme se, že takové vymezení povahy estetické zkušenosti v tvořivém postupu, v němž je $\mathrm{v}$ zachování charakteristiky přítomný i kontrast, je mimořádně příbuzné Whiteheadovým úvahám o povaze rytmu z pojednání Zkoumání o principech př́irodního poznání (An Enquiry Concerning the Principles of Natural Knowledge, 1919). A to i vzhledem k tomu, že „repríza“ názorů na povahu estetické zkušenosti z Náboženství ve vývoji uvedená v Procesu a realitě toto pojetí estetické zkušenosti explicitně spojuje s problematikou rytmu. V Procesu a realitě upozorňuje Whitehead na to, že „intenzivní zkušenost“, která je „estetickým faktem“ a která je kategoriálně určena na základě zobecnění „estetických zákonitostí jednotlivých umění, je odvozena od „kontrastu dědění a nového výsledku“. ${ }^{34} \mathrm{~V}$ takové kombinaci, kombinaci dědění a inovace, vzniká intenzivní „stabilní rytmický charakter“ pocitu. Tomuto pocitu je vlastní „váha opakováni“, „intenzita kontrastu“ a zároveň rovnováha obou těchto faktorů. Rovnováhu je ostatně

32 Tamtéž, s. 267-268.

33 Zde a dále srov. A. N. Whitehead, Religion in the Making, Cambridge, Cambridge University Press 1927, s. 101-102.

34 Zde a dále srov. A. N. Whitehead, Process and Reality, New York, The Free Press 1979, s. 279. 
zapotřebí spojovat s „vytrvalostí rytmu“, s jeho „stabilitou a intenzitou“, poukazuje tu také Whitehead.

Estetická zkušenost má tedy povahu pocitu, ve kterém je „kontrast“ přítomen jako součást určité „identity“. 35 Takový je rytmus. Je však zapotřebí říci, že Whiteheadovo vymezení rytmu ze Zkoumání o principech prírodního poznání je poněkud konkrétnější. Whitehead tu ukazuje, že rytmus je specifickým objektem zformovaným z jiných předmětů, které jsou „propletené na pozadí podstatné změny“ ${ }^{36}$ Rytmus zahrnuje určitý „Vzorec“ (pattern) a do této míry je „sebe-identický“. Zároveň však rytmus není pouhým opakováním vzorce. Rytmická kvalita je závislá na „odlišnostech“, které jsou „zahrnuty v každém předvedení vzorce“. Whitehead říká, že „podstata rytmu je splynutí stejnosti a novosti“. Rytmus tedy neztrácí „podstatnou jednotu vzorce“ a zároveň jeho součásti vykazují „kontrast“ vyvstávající z „novosti jeho detailư“. Kontrast je s rytmem podstatně spojený, protože rytmus je rozbit „pouhým návratem“ stejného stejně jako „pouhým splynutím rozdílü“. Rytmus není založen ani na pouhém splynutí, ani na jednoduché ,jednotvárnosti“. Rytmus není ani „vzorcem“ v jeho „neohybném návratu“, ani „události““ jako prostým „přechodem“. Rytmický tedy není ani krystal, v němž je př́itomna jednotvárnost stejného, ani mlha, kterou charakterizuje splynutí.

Domníváme se, že zmíněné Whiteheadovo pojetí Krásy jako harmonie kontrastů ve vztahu součástí celku k tomuto celku samotnému je možné bližším způsobem popsat pomocí této Whiteheadovy charakterizace rytmu jako spojení identity a kontrastu. Díky rytmu je dosaženo harmonie masivnosti rozmanitosti kontrastních prvků, protože rytmus má tendenci tuto mnohost organizovat, podržovat ji v sobě. S rytmem je však spojena nejenom určitá stálost harmonie, ale i její proměna, a to samozřejmě vzhledem k nástupu dalších a dalších prvků rytmu. Rytmus se odehrává a takovéto dění vede k proměně vztahu částí k celku a celku k částem. To, že konfigurace jako harmonie v kontrastu má z Whiteheadova hlediska charakter inovativního dění, to znamená proměny v udržování návaznosti, dosvědčují formulace, v nichž Whitehead poukazuje na to, že princip syntézy jednotlivých kontrastních objektů není daný v nich samotných a v odpovídajících jednotlivých subjektivních prehenzích, ale je odvozován z „nové jednoty“, kterou jednotlivým prehenzím ukládá „nové tvoření v procesu konstituce“. ${ }^{37}$ Samotná povaha harmonie v kontrastu se jako konfigurace neustále proměňuje. Whitehead také říká, že „bezprostřední událost“ dodává chybějící určení syntézy kontrastních objektů a subjektivních prehenzí z vlastní „spontaneity“. Domníváme se, že přesně takovou spontánnost bezprostřední události představuje rytmus jako proměňující se organizace mnohosti opakujících se elementů, tedy „opakujících se“ vzorců.

Chceme poukázat na to, že Whiteheadově výše uvedenému obecnému popisu povahy rytmu odpovídá Bergsonův způsob přiblížení rytmu z Eseje o bezprostředních datech vědomí. Dokonce se domníváme, že poněkud paradoxně znějící Whiteheadovo vymezení rytmu, ve kterém se hovoří o opakování vzorce a zároveň o odlišnostech v každém předvedení vzorce a také o spojení opakování a novosti, je díky Bergsonovým úvahám o rytmu konkretizováno. A to přesto, že Bergsonova charakterizace bezprostřední danosti

35 Srov. tamtéž, s. 280.

36 Zde a dále srov. A. N. Whitehead, An Enquiry Concerning the Principles of Natural Knowledge, Cambridge, Cambridge University Press, 1919, s. 198.

37 Zde a dále srov. A. N. Whitehead, Adventures of Ideas, viz výše, s. 255. 
rytmického uspořádání je formulována také paradoxním způsobem. Bergsonovo hledisko však tuto paradoxnost názorněji ukazuje jako nezbytnou, protože povaha rytmického uspořádání principiálně neodpovídá možnostem přesného pojmového určování.

Bergson v souvislosti se zvukovým či pohybovým rytmem, např́klad se zvukovým rytmem odbíjejících věžních hodin či obrazovým rytmem pohybů kyvadla hodin nástěnných, hovoří o „rytmické organizaci“ 38 Tato rytmická organizace však znamená neustálou proměnu počitku způsobeného zvukovým nebo obrazovým rytmem. S každým dalším zasahujícím zvukem či pohybem se rytmická organizace, to znamená aktuálně dosahovaný souhrn rytmizovaných zvuků či pohybů, ve vědomí proměňuje. Tato proměna ostatně vysvětluje i rozdíl v účinnosti mezi krátce a dlouze trvající realizací rytmu na vědomí, například zvyšující se hypnotizující, uklidňující nebo uspávající účinek. Rytmizované zvuky či pohyby jsou tudíž stejné výhradně z hlediska rozložení těchto elementů do prostoru. Když tvrdíme, že součástí rytmické organizace jsou stejné, opakující se počitky zvuků či pohybů, nehovoříme o počitcích samotných, o počitcích v reálném čase, v „trvání vědomí, ale o počitcích rozložených do prostoru. Opakování v přesném smyslu v rytmické organizaci neexistuje. Opakující se elementy se v ní neopakují, protože společně s předchozími elementy neustále proměňují podobu dosahovaného souhrnu, proměnu mnohosti, kterou vytvářejí, od které jsou neoddělitelné, které jsou součástí. O každém novém souhrnu se dá říci, že rozvíjí souhrn předchozí, a to jak ve smyslu návaznosti, tak i rozdílu. Rytmus rozhodně není ani návratem, ani splynutím, je neustálým přetvářením, neustálou inovací mnohosti jeho elementů. Rytmus tedy není jednotvárností. Z tohoto hlediska se dá dokonce říci, že rytmus je jednotou návaznosti a kontrastu, tuto jednotu ovšem musíme pojmout jako neustálé přetváření. ${ }^{39}$

Vratme se však k realizaci rytmu v estetické zkušenosti obecně a zkušenosti s uměním zvlášt. Mưžeme říci, že - z hlediska Whiteheadových úvah - není rytmus, se kterým se v krásném jevu, například v umění, setkáváme, od skutečnosti oddělen, že uspořádání harmonie v kontrastu, to znamená „Krása“, je neustále v kontaktu s „Pravdou“. Umění směřuje $\mathrm{k}$ „Pravdivé Kráse“, říká Whitehead. ${ }^{40}$ Není-li v umění přítomna pravda, kráse schází „mohutnost“, není-li v umění prrítomna krása, pravda je „triviální“. V Dobrodružství idejí nacházíme i vyjádření odlišující krásu a pravdu slov. S krásou - či spíš s vrcholnou krásou - je spojena „pravda citu, nikoli slov“. Tato pravda citu leží ve srovnání s předpoklady verbálního myšlení mnohem „hlouběji“, „nachází se mimo slovníkový význam slov.“ Uvedená vyjádření samozřejmě velice připomínají formulace ze Symbolismu, kde se pojednává o odlišnosti mezi prezentující bezprostř̌edností a kauzalitou. Vrcholná krása v jevu, který je nabízen např́íklad v umění, tedy v sobě nezbytně nenese pravdu bezprostřednosti. Rytmus jako proměnlivá a zároveň stabilní organizace mnohosti znamená organizaci této Pravdy bezprostřednosti věcí a pocitů. Rytmická bezprostřednost umožňuje takovou mohutnost a intenzitu zkušenosti, kterou obvyklá zkušenost postrádá nebo ji nevykazuje v dostatečné míře. Jakožto rytmická je bezprostřednost viděna a cítě-

38 Zde a dále srov. H. Bergson, Essai sur les donnés immédiates de la conscience, viz výše, s. 78-79.

39 Bergson poukazuje, že rytmická organizace je jako „hudební fráze“, která je „neustále u svého konce“, přičemž se u tohoto konce neustále modifikuje její „totalita“ zasahováním nových tónů. Hudební fráze je tedy organizována jako proměňující se „rytmus souhrnu“, o němž Bergson také hovoří. Srov. tamtéž, s. 92.

40 Zde a dále srov. A. N. Whitehead, Adventures of Ideas, viz výše, s. 267. 
na jako krásná, protože rytmické uspořádání zamezuje vzájemnému potlačování pocitů, kterým je intenzita a mohutnost bezprostřednosti překryta. Především je však, jakožto rytmická, tedy intenzivní a mohutná, bezprostřrednost teprve viděna, to znamená, že se nabízí jako pravda.

Domníváme se, že velice obdobnou roli nese rytmus také v Bergsonových úvahách o umění. Ty směřují k tomu, že umění představuje sugesci pravdy jako rytmické zákonitosti. O rytmickém působení umění Bergson explicitně uvažuje, když poukazuje na to, že rytmus je prostředkem sugesce individuality věcí a citů. V Eseji o bezprostředních datech vědomí uvažuje Bergson o půvabu, který se stupňuje až do podoby fyzikální sympatie, jíž je rytmické spojení mezi umělcem a divákem. Pomocí tohoto spojení fyzikální sympatie jsou divákovi sugerovány umělcem sdělované city. $V$ případě navázání tohoto spojení se divákovo vědomí a vůle proměňuje v rytmus. Je tedy zřejmé, že i to, co je sugerováno, má nezbytně rytmickou podobu. To, že prostřednictvím rytmu uměleckého díla vstupuje do vědomí cizí trvání v podobě rytmu, dokazují například Bergsonova vyjádření, s nimiž se setkáváme v jeho Smíchu. Bergson tu pracuje s myšlenkou hierarchizace jednotlivých umění, a to z hlediska toho, na kterou oblast vždy jedinečné skutečnosti se tato umění zaměřují. Tato hierarchizace má podobu určitého sestupu do vědomí jeho hloubky. Zatímco malířství a sochařství se zaměřují na jedinečnost barev a tvarů, poezie se zaměřuje na jedinečnost citů. ${ }^{41}$

Jedinečné skutečnosti - at už jsou to vnímané kvality či city - díla jednotlivých umění sugerují za pomoci rytmického uspořádání obrazů či slov. Nejhlouběji však dostupuje hudba. Zatímco ostatní umění vždy souvisejí se skutečnostmi, které se dají vyjádřit pomocí obrazů či slov, hudba už s takovými skutečnosti nemá cokoli společného, a zmocňuje se určitých „rytmů života“, zmocňuje se „živého zákona měnícího se u každé osoby, zákona jejích depresí a nadšení, jejích lítostí a nadějí“ 42 Zároveň však nepochybná blízkost a zásadní příbuznost mezi jednotlivými uměními poukazuje na to, že umění zabývající se povrchnějšími skutečnostmi se dají vyložit jako určité převedení do vnějšku toho, co je odhaleno, to znamená toho, co je sugerováno hudbou. To, že ostatní umění na rozdíl od hudby neukazují zvláštní rytmus individuálního vědomí, tedy rytmickou zákonitost, která je u každého člověka jiná, neznamená, že se ostatní umění k této individuální rytmické zákonitosti nevztahují. I to, co sugerují ostatní umění, je od individuálního rytmu odvozeno, protože jakékoli výsledky vnímání či jakékoli city jsou součástí života individuálního člověka, a jsou tedy součástí realizace jeho individuální rytmické zákonitosti. Domníváme se proto, že Bergson ve Smíchu výrazně poukazuje na to, že rytmem je $\mathrm{v}$ umění sugerována pravda jako rytmus.

To, že je v umění nabízen rytmus jako pravda, však Bergson potvrzuje i na jiných místech. V pojednání „Život a dílo Félixe Ravaissona“ ukazuje, že v malířství směřuje k zachycení živé bytosti. Živá bytost má však povahu vlnité linie či serpentinaty, přičemž jednotlivá živá bytost se od ostatních odlišuje vlastním způsobem „Zvlněnosti““ ${ }^{3}$ Předmětem umění je zpodobovat toto „individuální zvlněni“" tuto vždy individuální povahu vlnité linie. Toto zvlnění se dá vykládat jako skutečnost pohybu, za pohybem však je

41 Bergson, H., Le rire, viz výše, s. 119.

42 Tamtéž, s. 120.

43 Zde a dále srov. H. Bergson, Život a dílo Félixe Ravaissona, viz výše, s. 254-255. 
možné rozeznat ještě něco „tajemnějšího“ - či řekněme ještě něco hlubšího - a to „nejzákladnější aspirace“ dotyčné bytosti, její „prvotní směřování, prosté myšlení. Domníváme se, že blízkost těchto poznámek zmíněnému Bergsonovu vyjádření z pojednání Smích je zřejmá a že zvlnění hluboké aspirace, k němuž umění směřuje, je zapotřebí vykládat jako rytmus života zpodobované bytosti.

Zároveň chceme zdůraznit, že v Bergsonových vyjádřeních věnovaných rytmickému uspořádání v uměleckém díle, kterým jsme se věnovali, je naznačeno rovněž to, že hluboký, či snad tajemný rytmus, k němuž dílo směřuje, ovládá povrchnější pohyby. Takovým pohybem je vývoj citů a vývoj myšlení určité osoby, a patrně i vlnění viditelných barev a tvarů na zachycovaném modelu. I za těmi „nejniternějšími city“, kterým nepochybně musíme připsat charakter živého pohybu, a tedy pravděpodobně i charakter rytmického vlnění, leží rytmus jako „živá“, a tudíž naprosto individuální zákonitost proměn povrchnějších pohybů. Myšlenku shrnutí pohybů či rytmů v základnějším pohybu či rytmu, se kterou se u Bergsona setkáváme v takovémto náznaku, tematizuje Whitehead. S životem je, na rozdíl od fyzického předmětu, spojeno „vyjádřeni““ rytmu a „citlivost“ $\mathrm{k}$ rytmu. Život je „spojením“ rytmů, ${ }^{44}$ je „komplexitou“ rytmů. ${ }^{45}$ Život jako rytmus vykazuje „rozdíly ve stupni“, „vyšší a nižší stupeň“, přičemž nižší je předpokladem existence vyššího. Život je dokonalejším rytmem, který zahrnuje rytmy méně dokonalé, je „komplexním“ rytmem, který zahrnuje rytmy „jednoduché“. A jestliže Whitehead v této souvislosti poukazuje na to, že „život je ve svém vyjádření komplexem, který zahrnuje více než jen vnímavost, a to totiž touhu, cit, vůli a pocit“" 46 domníváme se, že o vnímání, touhách, citech, volbách a pocitech můžeme hovořit jako o jednodušších rytmech zahrnutých či shromážděných do komplexního rytmu určitého života. Vzhledem k uvedenému charakteru estetické zkušenosti nebo zkušenosti s uměním se dá hovořit o větší či menší hloubce této zkušenosti na základě dosaženého stupně shrnujícího rytmu, tedy na základě dosaženého stupně komplexity zahrnutých rytmů. V Eseji o bezprostředních datech vědomí hovoří Bergson o stupních „intenzity“ estetického citu a stupních „hloubky“ či „povzneseni“ tohoto citu. ${ }^{47}$ Zatímco stupně intenzity odpovídají síle, kterou se vědomí rytmicky sugerovaný cit zmocňuje, stupně hloubky či povznesení odpovídají bohatosti, jíž se sugerovaný cit vykazuje. Bohatý cit je těhotný „tisíci počitků, citů a myšlenek, které se pronikají. ${ }^{48}$ Avšak vzhledem k tomu, že sugerovaný cit vstupuje do vědomí jako rytmus, musíme bohatství sugerovaného citu považovat za bohatství elementů tohoto rytmu, tedy za rytmizované složky, jež se pronikají. Individuální život představující zvláštní rytmus cítění, a myšlení se tak jeví jako pronikání či syntéza rytmických proudů.

\section{Rytmus a skutečnost}

Výsledek, ke kterému docházíme, tedy to, že v estetické zkušenosti obecně a v uměleckém díle zvlášt je odhalena rytmická podoba určité oblasti skutečnosti, se z pohledu

44 Srov. A. N. Whitehead, An Enquiry Concerning the Principles of Natural Knowledge, viz výše, s. 197.

45 Srov. tamtéž, s. 199.

46 Srov. tamtéž, s. 197.

47 Zde a dále srov. H. Bergson, Essai sur les données immédiates de la conscience, viz výše, s. 13-14.

48 Tamtéž, s. 13. 
Whiteheada a Bergsona nemůže jevit nijak překvapivý. Naopak: Whitehead i Bergson poukazují na to, že skutečnost má v jistém univerzálním smyslu povahu rytmického spektra. Skutečnost je složena $\mathrm{z}$ různých rytmů, rytmů jednoduchých a složitých nebo uvolněných a napjatých.

Ve svém Zkoumání o principech prírodního poznání Whitehead poukazuje na to, že ve fyzickém předmětu se rytmus ztrácí, protože takovýto předmět představuje $\mathrm{z}$ určitého hlediska „makroskopické nakupení rytmů, jeví se jako „průměr rytmů“, z něhož není vystavěn „žádný rytmus“ ${ }^{49}$ Takové nakupení se jeví jako neživé - je z tohoto hlediska neživou „hmotou“ - právě vzhledem k tomu, že už nevykazuje žádný rytmus. Naproti tomu život je vždy spojen s „vyjádřením rytmu“ a s „citlivostí vůči rytmu“. Whitehead konstatuje, že ve srovnání s rytmy, z nichž je vytvořeno nivelizující „nakupení fyzického předmětu, je život spojen s „komplexnějšími, jemnějšími“ rytmy. Zjevnost rytmu je charakteristickou vlastností toho, čemu přičítáme život, tedy „kdekoli je rytmus, je život“. Rytmus však vykazují i „složky“ fyzického předmětu, a to jestliže svou pozornost odvrátíme od „jednotvárného“ předmětu jako neživého nakupení k „situaci“ těchto složek samotných. Mnohost těchto složek je mnohostí rytmických pohybů molekul. I pohyby molekul jsou rytmem, přestože je to rytmus „mimořádné jednoduchosti“ ${ }^{50}$ Molekula je však „ne-jednotvárným předmětem a jako taková vykazuje rytmus“ ${ }^{51}$ Whitehead v této souvislosti sleduje myšlenku, že z těchto mimořádně jednoduchých rytmů se skládají komplexnější rytmy, s nimiž je spojena povaha života. Molekula je „vzorcem“ zařazeným do rytmu, „vtiskujícím se“ do „rytmu“.52 Její „atomární povaha“, tedy povaha vzorce, však do rytmu nevnáší „diskontinuální existenci“, protože rytmus molekuly má povahu vlnění a př́slušnou „vlnovou délkou“ je rytmus určen ve „svém průběhu na každém místě svého kontinuálního pohybu“. Molekuly tedy nejsou jednoduše fyzickými předměty v jejich „stabilizované existenci“, přestože vytvoření takovéto stability existence vždy zároveň umožňují. Jako „ne-jednotvárné“ jsou molekuly součástí „zjevně komplexního“ rytmického uspořádání, které se $\mathrm{v}$ přírodě nabízí a které dokážeme pozorovat díky našemu způsobu jejich „uchopení. Na jedné straně je to „těkající rytmus“ živého těla, kterým je neustálé přijímání a odmítaní materiálu, na straně druhé je to vědomí, tedy „rytmus-nesouci“" skutečnost, s níž je spojena schopnost - či „úhel pohledu“ umožňující - takovýto př́rodní rytmus rozpoznávat.

Na základě Whiteheadových poznámek je tedy možné říci, že z určitého hlediska je skutečnost skutečností rytmů v jejich vzájemné návaznosti a zahrnování, a to od nejjednodušších molekulárních rytmů přes rytmus živého těla až po složitý rytmus vědomí. Je až překvapivé, nakolik se Whiteheadovo uvažování přibližuje Bergsonově koncepci rytmické povahy skutečnosti, přesněji řečeno pojetí univerza jako spektra rytmů. Ve svém pojednání „Úvod do metafyziky“ (1903) poukazuje Bergson na to, že je zapotřebí předpokládat rozdílné úrovně trvání odlišné od našeho. ${ }^{53}$ Od našeho trvání můžeme na jedné straně sestupovat k trvání stále „rozptýlenějšímu“, jehož rytmus je „rychlejší“ ve

49 Zde a dále srov. A. N. Whitehead, An Enquiry Concerning the Principles of Natural Knowledge, viz výše, s. 197.

50 Srov. tamtéž, s. 199.

51 Tamtéž.

52 Zde a dále srov. tamtéž, s. 198-199.

53 Srov. H. Bergson, Úvod do metafyziky, in: H. Bergson, Myšlení a pohyb, viz výše, s. 204. 
srovnání s rytmem našeho trvání. Toto rozptýlené trvání má nakonec povahu „pouhého opakováni“ dění v homogenním prostoru. Na straně druhé můžeme vystupovat k trvání stále „napjatějšímu, soustředěnějšímu a intenzivnějšímu“. Toto intenzivní trvání má nakonec povahu „věčného“ pohybu života.

Jak je možné chápat vztahy těchto rozdílných rytmických úrovní, ukazuje Bergson na jiných místech, nejvýrazněji však ve studii „Vnímání změny“. Bergson tu konstatuje, že např́iklad jakýkoli barevný odstín je ve skutečnosti „nekonečně rychlou oscilací, fyzikálním vlněním, neustálou změnou a pohybem, s nímž nemůžeme spojovat cokoli stálého.

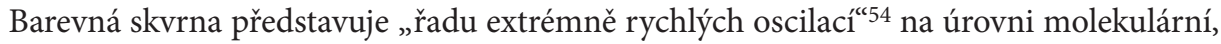
atomární či částicové. ${ }^{55} \mathrm{~S}$ obdobnou kontinuální změnou se setkáváme také ve vývoji našeho duševního života. Bergson však ukazuje, že „mechanismus našeho vnímání“ a „mechanismus našeho působení" na předměty je „seřízený “ takovým způsobem, že tuto pohyblivost věcí a pohyblivost našeho vědomí redukuje na stabilitu, že pohyblivost věcí i vědomí redukuje na řadu stavů, kterými věci a vědomí s nimi konfrontované prochází. Tato předpokládaná řada stavů zakrývá nepřetržitost změn ve věcech i ve vědomí, napomáhá praktickému jednání, nebo ho spíš jako takové umožňuje. Bergson poznamenává, že je opravdu „užitečné“ setkávat se se „stabilními“ předměty, ${ }^{56}$ to znamená s předměty charakterizovanými i stabilními smyslovými kvalitami, např́klad barevnými odstíny.

Tyto formulace nepochybně odrážejí směřování Bergsonových úvah z významného pojednání Hmota a pamět' (1896). Bergson tu poukazuje na to, že veškerá skutečnost je pohybem, který však nemůžeme chápat jako přemístování. O jakémkoli pohybu musíme hovořit jako o kvalitativní proměně, vlastní skutečnost pohybu je „kvalitou samotnou, vnitřně se takříkajíc chvějící a udávající rytmus vlastní existence“ až „nevyčíslitelným počtem okamžikü“ ${ }^{57} \mathrm{O}$ pohybech se tedy dá říci, že jsou „nedělitelnými jednotkami“, které „zabírají určité trvání, předpokládají nějaké před a nějaké po, „spojují po sobě jdoucí okamžiky vláknem“, které není nepodobné souvislosti našeho vlastního vědomí, protože jejich „kvalita se obměňuje“ obdobně jako kvalita toho, co ve vědomí prožíváme. A naopak vnímané kvality věcí jsou ve skutečnosti výsledkem „smrštění ohromného množství po sobě jdoucích okamžiků, záchvěvů tvořících samu podstatu pohybu, tedy smrštění „trilionů záchvěvư“. Tuto závislost vnímání kvalit na vibracích pohybu můžeme pozorovat v př́ípadě, že rytmus pohybu je dostatečně pomalý, dostatečně ladí s „návyky našeho vědomí, tedy s úrovní napětí našeho vědomí, jako je tomu např́iklad „u hlubokých tónů hudebních škál“.

V takovém prrípadě cítíme, že se vnímaná kvalita „rozkládá na opakované a po sobě jdoucí záchvěvy, vzájemně spojené určitou vnitřní souvislostí“. Vnímat však obecně znamená „zhuštovat obrovské periody nekonečně rozředěné existence do několika význačných chvil intenzivního života“, znamená to „shrnovat dlouhý př́běh“ do několika okamžiků, vnímat znamená „znehybňovat“ ${ }^{58}$ Lidské vnímání „smrštuje do jediného okamžiku“ vlastního trvání „to, co by se samo o sobě rozkládalo v nevyčíslitelném množství okamžikư“. Beze vztahu k trvání vědomí, to znamená beze vztahu ke specifické úrovni

54 H. Bergson, Vnímání změny, viz výše, s. 161.

55 Srov. tamtéž, s. 160.

6 Srov. tamtéž, s. 159.

57 Zde a dále srov. H. Bergson, Hmota a pamět', OIKOYMENH, Praha 2003, s. 151-152.

58 Zde a dále srov. tamtéž, s. 154-155. 
rytmického napětí trvání, kterým je podmíněno lidské působení na předměty, se předměty rozdělí do nepředstavitelného množství okamžiků. Jejich smyslové kvality „nezmizí, ale „rozprostřou se a rozpusti“ v „nesrovnatelně více rozděleném trvání. Můžeme tedy říci, že ve vnímání, s nímž je spojena schopnost působení na předměty, se toto rozdělené trvání nevyčíslitelných oscilací smrštuje do stabilizované kvality.

Bergson však v souvislosti s vnímáním kvalit hovoří i o „procesu“ či „aktu“, který umožňuje „V kvalitě samotné uchopit nebo vycítiti cosi, co přesahuje počitek“, jako by počitek v sobě obsahoval „plno tušených a nevnímaných detailü “ ${ }^{59}$ Objektivnost počitku spočivá „V obrovském množství pohybů“, které vykonává uvnitř vlastní „schránky“. Počitek se na povrchu „rozkládá v nehybnosti“, „uvnitř se však chvěje a žije“. Dovolíme si tedy říci, že Bergson předpokládá schopnost lidského vědomí odhalit něco z proměn pohybu oscilace, která je obvykle skrytá za vymezenými předměty a jejich danými a domněle stálými kvalitami, nebo lépe řečeno, schopnost povšimnout si působení proměn této oscilace v proměnách vnímaných kvalit věcí. Obdobným způsobem se však Bergson o vztahu kvality a oscilace vyjadřuje i ve „Vnímání změny“. K „oscilaci“ barevného odstínu, o níž Bergson hovoří také jako o „pohybu pohybu“, 60 se vztahuje naše vnímání. Vnímat proměnlivost tohoto odstínu, který závisí na proměně její oscilace, však „není v našem zájmu“. V našem zájmu je naopak redukovat výsledky proměny oscilace na stálost uchopitelných vlastností snadno identifikovatelných předmětů. S těmito uchopitelnými předměty můžeme nakládat $\mathrm{k}$ našemu prospěchu. Oproti tomuto selektivnímu způsobu vnímání věcí však existuje i možnost našeho ponoření do vnímání, abychom je prohloubili a rozšírili. Toto ponoření se realizuje prostřednictvím našeho úsilí, do něhož se zapojí naše vidění věcí. V takovém „úsilí “ jsou naše smysly a naše vědomí vybídnuty k tomu, aby „poskytly všechno, co je dáno“, lépe řečeno, aby „poskytly více“ oproti tomu, co „přirozeně skýtají“ 61

Dá se říci, že v takovém rozšířeném vnímání jsou zachycovány účinky zmíněných nepředstavitelně rychlých oscilací v jejich proměnách. Rozšířené vnímání je tedy zaměřeno na zachycení proměn vnímaných smyslových kvalit věcí, v nichž se odrážejí proměny odpovídajících oscilací. A Bergson ukazuje, že naši schopnost tohoto rozšířeného vnímání dokazuje zřetelně především umění. Umění ukazuje to, co jsme zahlédli, ale čeho jsme si nepovšimli, ukazuje nepovšimnutou pravdu věcí i našeho vědomí, ukazuje námi už výše zmiňované „nepovšimnuté aspekty“ věcí, tedy „bleskové a pomíjivé výjevy“, kterými je přesažena stabilita kvalit v obvyklém vnímání směřujícím k obecnosti.

V Bergsonově pojetí tedy napjatější rytmus sugerovaný v umění představuje smrštění rychlejších, méně napjatých rytmických oscilací. Na rozdíl od smrštění těchto oscilací v obvyklém vnímání však rytmus v umění naznamená nivelizaci jejich proměn, potlačení těchto proměn $v$ přenesení pozornosti k praktické využitelnosti věcí či sdělitelnosti pocitů a myšlenek. Rytmus sugerovaný v umění neztrácí pružnou souvislost s těmito oscilacemi, naopak jeho proměny odrážejí proměny těchto oscilací. Bezprostřednost skutečnosti odkrytá v umění a její harmonizace náleží jako rytmus zvláštní úrovně do rytmického spektra skutečnosti, s nímž je - na rozdíl od obvyklé zkušenosti - citlivě svázána.

59 Zde a dále srov. tamtéž, s. 152-153.

60 Zde a dále srov. H. Bergson, Vnímání změny, viz výše, s. 162.

61 Srov. tamtéž, s. 145. 
S myšlenkou zasazení estetické zkušenosti do spektra oscilací se však setkáváme i u Whiteheada v Symbolismu. Whitehead tu spojuje estetickou emoci s působením zvukového nebo světelného vlnění. Toto vlnění estetickou emoci způsobuje nebo alespoň významně ovlivňuje její charakter. Whitehead konkrétně poukazuje na to, že vzniklý „př́ijemný stav" estetické emoce je následně symbolicky přenášen na smyslové vnímání, v některých př́padech je však takový přenos nemožný, protože je charakter estetické emoce způsoben oscilací ležící mimo oblast spektra působícího na lidské vnímání. ${ }^{2} \mathrm{Na}-$ př́klad ultrafialové paprsky, tedy „součást spektra slunečního světla“, kterou není způsobováno vnímání některého barevného odstínu, vyvolávají „nepopiratelný emocionální účinek“. Obdobně také zvuky těsně nad nebo těsně pod prahem slyšitelnosti „zjevně přidávají emocionální účinek" $k$ estetickým účinkům symbolicky spojovaným se zvukem v jeho slyšitelném rozsahu. Můžeme doplnit, že na obdobnost mezi fyzikální oscilací a principem estetické zkušenosti Whitehead upozorňuje i v Náboženství ve vývoji, když poukazuje na to, že princip kontrastu $\mathrm{v}$ identitě je př́tomný ve fyzikálních vibracích vstupujících do „nejzákladnějši přirozenosti atomárních organismư“ ${ }^{63}$ Fyzikální vibrace jsou - i když jsou popisovány v prostředí abstrakcí fyzikální vědy - vyjádřením „podstatného principu estetické zkušenosti“.

Přes odlišnost $\mathrm{v}$ zaměření uvedených Bergsonových a Whiteheadových vyjádření k zasazení estetické zkušenosti do spektra oscilací, tedy rytmického vlnění skutečnosti, chceme zdůraznit samotnou tendenci obou myslitelů vztáhnout estetickou problematiku k tomuto kontextu. Přiblížení povahy estetické zkušenosti či zkušenosti s uměním je u Whiteheada i Bergsona nakonec podloženo úvahami o podstatě vnímání, kterou spatřují v shrnutí či shromáždění atomární oscilace. A estetická zkušenost či zkušenost $\mathrm{s}$ uměním je konkrétní podobou těchto oscilací určována. Bergson $\mathrm{v}$ této souvislosti předpokládá, že na rozdíl od obvyklého vnímání odrážejí vlastnosti věcí vnímané na základě umělecké sugesce proměnlivou podobu vlnění shrnovaného ve vnímání. Whitehead naopak poukazuje na to, že na konkrétní emocionální stav v estetické zkušenosti působí nejenom oscilace, kterými můžeme vysvětlit charakter toho, co aktuálně vnímáme, ale i oscilace, které nemají na vnímané vlastnosti vliv.

\section{Závěry}

V př̀edložené studii jsme se pokusili ukázat, že odhalování bezprostřední skutečnosti, na niž se soustředuje umění a s níž můžeme ztotožnit estetickou zkušenost jako takovou, má podle Whiteheada i podle Bergsona povahu harmonizace obvyklé zkušenosti, a to do podoby rytmu. Whiteheadovým a Bergsonovým úvahám o rytmu jsme se dále věnovali podrobněji a poukázali jsme na to, že jejich názory se v několika ohledech doplňují, či dokonce překrývají. V této souvislosti jsme se zabývali samotným vymezením rytmického uspořádání jako pokračování, ve kterém nedochází k opakování, ale k neustálé inovaci. Upozornili jsme také na to, že s rytmickým uspořádáním, s nímž se setkáváme

${ }^{62}$ Zde a dále srov. A. N. Whitehead, Symbolismus, jeho význam a účin, viz výše, s. 62.

63 Zde a dále srov. A. N. Whitehead, An Enquiry Concerning the Principles of Natural Knowledge, viz výše, s. 102. 
v uměleckém díle i v estetických jevech obecně, je spojován především status pravdy. A poukázali jsme i na to, že toto rytmické uspořádání má charakter komplexu rytmických proudů. Nakonec jsme upozornili na to, že Whiteheadova a Bergsonova myšlenka odhalování bezprostřední skutečnosti jako rytmu se ve světle jejich úvah o podobě univerza jako spektra různých rytmů nemůže jevit nikterak překvapivá. Rytmus nabízený v uměleckém díle, př́ípadně rytmus, s nímž se setkáváme v estetické zkušenosti obecně, je z tohoto hlediska rytmem specifické intenzity a také specifické složitosti. Je však spojen s ostatními rytmickými úrovněmi univerza, je zejména kondenzací napětí nižších úrovní a kompozicí jednodušších úrovní uspořádání. Díky tomu však do něho tyto jiné úrovně zasahují, svým charakterem a svou proměnlivostí ho ovlivňují smyslově vnímatelným i emocionálním způsobem.

\section{Poděkování}

Za cenné připomínky a návrhy bych rád poděkoval Martinu Kaplickému a Ondřeji Dadejíkovi. Text vznikl za podpory grantového projektu GA16-13208S Proces a estetika: explicitní a implikovaná estetika v procesuální filozofii Alfreda North Whiteheada.

\section{LITERATURA}

Bergson, H., Dva zdroje morálky a náboženství, Vyšehrad, Praha 2007.

---, Essai sur les donnés immédiates de la conscience, PUF, Paris 1998.

---, Hmota a pamět', OIKOYMENH, Praha 2003.

---, Le rire, essai sur la signification du comique, PUF, Paris 1999.

---, Myšlení a pohyb, Mladá fronta, Praha 2003.

Robinson, K., Introduction: Deleuze, Whitehead, Bergson - Rhizomatic Connections, in: Robinson, K. (ed.), Deleuze, Whitehead, Bergson: Rhizomatic Connections, Palgrave Macmillan, Houndmills 2009, s. $1-27$.

Ševčík, M., Umělecká tvořivost v úvahách A. N. Whiteheada a H. Bergsona, Acta Universitatis Carolinae. Philosophica et Historica. Studia Aesthetica, č. 1, 2017, s. 51-59.

Whitehead, A. N., Adventures of Ideas, The Free Press, New York 1933.

---, An Enquiry Concerning the Principles of Natural Knowledge, Cambridge University Press, Cambridge 1919.

---, Process and Reality, The Free Press, New York 1979.

---, Religion in the Making, Cambridge University Press, Cambridge 1927.

---, Symbolismus, jeho význam a účin, Panglos, Praha 1998. 